\title{
Effect of SME Food Entrepreneurs Knowledge on Halal Certification for Certified Awareness using Partial Least Square
}

\author{
Ida Giyanti a*, Erna Indriastiningsih ${ }^{b}$ \\ a Industrial Engineering Department, Universitas Setia Budi, Indonesia \\ Jl. Letjend Sutoyo Mojosongo-Jebres-Surakarta, 57127, Indonesia \\ b Industrial Engineering Department, Universitas Sahid Surakarta, Indonesia \\ Jl. Adi Sucipto 154, Jajar-Laweyan-Surakarta, 57144, Indonesia \\ * Corresponding author: idagiyanti@setiabudi.ac.id
}

\section{ARTICLE INFO}

Article history

Received January 1, 2019

Revised June 1, 2019

Accepted July 1, 2019

Available Online August 31, 2019

Keywords

Halal Certification

Partial Least Squares

Small Medium Enterprise

Structural Equation Model

\begin{abstract}
This study aims to predict the impact of the understanding of halal certification by Small Medium Enterprise (SME) entrepreneurs to conduct halal certification. This study was conducted in SMEs in Surakarta, Indonesia. The Halal Certification Comprehension Rate was assessed using three variables. We used knowledge of halal (PGT), perceived halal certification advantages (MNF), and perceived halal certification procedures (PROS). Structural Equation Model-Partial Least Squares (SEM-PLS) was used for data analysis. The results show that SMEs have a good knowledge of halal and agree that halal certification is beneficial to their businesses. We found, though, that the processes for handling Halal Certification are relatively complex. Based on the study, the perception of Halal Certification Benefits (MNF) is significantly affected by the intention of SMEs to conduct Halal Certification (NHL). The other two results show a positive correlation. However, they are not statistically significant.
\end{abstract}

This is an open-access article under the CC-BY-SA license.

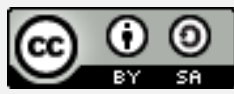

\section{Introduction}

Food is a fundamental human need. In the food field, Hexa Research estimated that the global halal food demand for 2024 had crossed US\$ 2.55 trillion [1]. Indonesia is a country with the largest Muslim population in the world. The potential of the Halal Food Product Market is significant and provides opportunities for small and mediumsized enterprises (SME). However, several small and medium-sized owners did not care about the halal status of food products made. In the Central Java province of Indonesia, $0.01 \%$ or 494 small and medium-sized enterprises (SMEs) have been granted Halal Certification. The percentage of SMEs that have never received a Halal Certificate is 3.92 percent [2]. Entrepreneurs assume that food products already use healthy and halal 
ingredients. They believe that they do not need to take care of halal certification. Therefore, It is essential to know the factors that influence the awareness/intention of SMEs to carry out Halal Certification on their products.

Based on previous studies, research limited the knowledge of halal certification from the SME point of view. Aziz and Chok [3] and Haque, et al. [4] described factors that influence the willingness of non-Muslim customers to buy halal food products. Aziz and Chok [3] explored the interaction between halal recognition, halal labeling certification labels, food quality, and promotional activities. It also discussed the need for non-Muslim buyers in Malaysia to purchase halal goods. Haque, et al. [4] described the factors that influence perceptions of Malaysian non-Muslim customers in purchasing halal food products using the Theory of Planned Behavior framework. Golnaz, et al. [5] and Rezai, et al. [6] investigated the perceptions of non-Muslim customers in Klang Valley, Malaysia, of halal food products. Mathew [7] and Ismail and Nasiruddin [8] measured the level of acceptance of Malaysian non-Muslim consumers of halal food. Furthermore, Wibowo and Ahmad [9] developed a conceptual model of the acceptance non-Muslim customers in Malaysia of halal food products.

Azmi, et al. [10] established factors that affect halal standards in the industry. Zailani, et al. [11] investigated the motivating factors which affect the implementation of halal strategies by industry. Maryati, et al. [12] and Prabowo, et al. [13] investigated the restriction factors in implementing halal criteria. Kusumastuti and Rachmawati [14] analyzed small and medium-sized enterprises' knowledge of halal certification. They established the driving factors and challenges facing them. Siaw and Rani [15] also stated that the introduction of halal compliance regulations is the biggest challenge for small and medium-sized businesses. Furthermore, Ab Talib [16] claimed that there are two motivating factors internal motivation and external motivation. Ab Talib, et al. [17] indicated that three external factors, like consumer demand, competitor pressure, and intimidation, affect the introduction of halal certification of food products. Waluyo [18] analyzed the factors that support halal certification in food producer companies.

Previous studies concluded that the driving factor for halal certification is the benefits of halal certification. In addition, there are external factors from the market, customers, competitors, and policy competencies. Constraint considerations include prices, certification processes, lack of information and socialization, managerial commitment, and issues related to SME competencies. No study studies the awareness/intention of SME entrepreneurs to carry out halal certification. This study explored the factors that encourage entrepreneurs to carry out Halal Certification. The selection of SMEs is the focus of this study, as SMEs dominate Indonesian food production. The results of this study are expected to design strategies for small and medium-sized enterprises to increase the level of SME Halal Food Certification. This article consists of four parts, as follows. The Introduction is described in Section 1. Section 2 contains the Research Methodology, which includes identifying variables and indicators, developing hypotheses and research models, data collection, and data analysis techniques. Section 3 explains the results and discussions. Section 4 contains the conclusions and further work.

\section{Methods}

\subsection{Identification of Variables and Indicators}

We used three factors to influence SME awareness and intention, such as Knowledge of halal (PGT), Perception of the Benefits of halal certification (MNF), and perception of procedures of halal certification (PROS). The knowledge of halal variable 
(PGT) was defined as the knowledge of halal-related SMEs in the food production process. Based on research by Waluyo [18] and Rafiki and Wahab [19], we developed measurement items for Halal Variable Knowledge (PGT). Variable perception of benefits (MNF) was described as an understanding by SMEs of the benefits obtained from the presence of halal labels on their products[16, 20,21]. The variable perception of the Halal Certification Procedure (PROS) is the awareness of SMEs towards the stage to receive Halal Certification from the Indonesian Council of Ulama (LPPOM-MUI) [20] [22]. The Intention Halal Certification (NHL) variable measures the level of awareness or the extent to which SME entrepreneurs want to meet Halal standards during the production process [18, 20, 22]. Measurement indicators for each factor in the study are shown in Table 1.

Table 1. Research variables and measurement indicators

\begin{tabular}{|c|c|c|c|}
\hline Variable & Indicator & Measurement item & Reference \\
\hline $\begin{array}{l}\text { Knowledge } \\
\text { (PGT) }\end{array}$ & $\begin{array}{l}\text { PGT2 } \\
\text { PGT3 }\end{array}$ & $\begin{array}{l}\text { Equipment for the production of processed halal } \\
\text { food/drink must be separated from other } \\
\text { equipment used for manufactured unclean } \\
\text { food/drink } \\
\text { Products containing alcohol used in the } \\
\text { production process are haram } \\
\text { Products of pork fat used in the production } \\
\text { process are haram }\end{array}$ & [18] [19] \\
\hline $\begin{array}{l}\text { Perception } \\
\text { of Benefits } \\
\text { (MNF) }\end{array}$ & $\begin{array}{l}\text { MNF1 } \\
\text { MNF2 } \\
\text { MNF3 }\end{array}$ & $\begin{array}{l}\text { Halal certification encourages SMEs to produce } \\
\text { high-quality food/drinks } \\
\text { Halal certification encourages producers to } \\
\text { improve production processes } \\
\text { Halal certification can be used as a consumer } \\
\text { promotional tool }\end{array}$ & $\begin{array}{l}{[18][20]} \\
{[21]}\end{array}$ \\
\hline $\begin{array}{l}\text { Perception } \\
\text { of } \\
\text { Procedures } \\
\text { (PROS) }\end{array}$ & $\begin{array}{l}\text { PROS3 } \\
\text { PROS4 }\end{array}$ & $\begin{array}{l}\text { The process is relatively easy to carry out Halal } \\
\text { Certification } \\
\text { Handling with electronic halal certification } \\
\text { (CEROL) helps small and medium-sized } \\
\text { enterprises (SMEs) } \\
\text { Time to take care of halal certification relatively } \\
\text { quickly } \\
\text { The cost of maintaining halal certification is low } \\
\text { for SMEs }\end{array}$ & {$[20][22]$} \\
\hline $\begin{array}{l}\text { Intention } \\
\text { Halal } \\
\text { Certification } \\
\text { (NHL) }\end{array}$ & $\begin{array}{l}\text { NHL1 } \\
\text { NHL2 } \\
\text { NHL3 }\end{array}$ & $\begin{array}{l}\text { I will register the products of SMEs to obtain } \\
\text { halal certification } \\
\text { Although I am sure Halal ingredients have been } \\
\text { used, I still responsible for the Halal Certification } \\
\text { I must try to meet Halal quality standards in } \\
\text { order to gain Halal certification. }\end{array}$ & {$[20][22]$} \\
\hline
\end{tabular}

\subsection{Models and Hypotheses}

The framework of this research model is shown in Fig. 1. Waluyo [18] discussed that religion is the most critical factor in the awareness/intention of Halal Certification. The level of knowledge of Islam had a strong and significant impact on the understanding of SMEs [19]. The variable of religious knowledge was calculated using 
the general understanding of religion [18] [19]. Religious understanding factors focus on halal/haram understanding. Therefore, the hypothesis $(\mathrm{H})$ in this study is as follows:

H1: The halal/haram knowledge levels have a positive effect on the intention/awareness of food SMEs to undertake halal certification

Halal/haram knowledge has a significant impact on awareness/intention to perform halal certification as a motivation to profit. Profit is the benefit of the existence of Halal Certification [21]. Several advantages of halal certification include increased sales, profits market share, labor productivity, number of employees, number of consumers, customer satisfaction, trust and loyalty, and export opportunities [21] [20]. In addition, halal certification was expected to increase the efficiency of the production process internally. Externally halal certification can promote the image and reputation of the organization in the eyes of consumers [16]. In this study, the motivation factor for profit was extended to include the perception of benefits related to halal certification. The second hypothesis developed in the study is as follows:

H2: The perception of SMEs of the benefits of halal certification has a positive effect on the intention/awareness of SME food entrepreneurs to perform halal certification.

Halal certification is a method for obtaining Halal certificates. The halal certification step proves that the components, the manufacturing process, and the halal assurance program meet the Indonesian Council of Ulama (LPPOM-MUI) requirements [23]. The Halal Certificate includes the certificate number and the date of validity of the certificate. Halal certificate is a prerequisite to receiving a Halal label license from LPPOM MUI on labeling the product. The halal certificate is valid for two years. Two months before the expiration date of the validity period, the entrepreneur must reregister his product to obtain a new halal certificate. SMEs need to go through many stages of the process. The stages of the halal certification cycle have been a limiting factor for some SME businessmen to implement halal certification [12] [13] [14]. The process of achieving halal certification is perceived to be complicated by the understanding of SME entrepreneurs. The complexity of halal procedures negatively and significantly affected producers to adopt halal [22]. The understanding of the halal certification phase was assessed in this analysis using positive indicators [20]. Therefore, the third theory, then, that was established in this study is:

H3: SMEs perceptions of ease of halal certification procedures have a positive impact on the intention/awareness of SME food entrepreneurs to conduct halal.

\subsection{Data Collection}

This study was conducted in Surakarta City, Central Java Province of Indonesia. The research focuses on food SMEs listed in Surakarta, Indonesia. The sampling technique used purposive sampling. Respondent's qualifications include leading food and beverage manager in SME that have not yet earned halal certificates from LPPOM-MUI. Surveyors visited respondents to affirm respondents willing to participate in surveys. One hundred ten respondents participated in this research. Moreover, just 98 questionnaires, in the data processing. The data collected in this study used questionnaires. Question items on the assessment measure used the Likert scale from "1" to "5." The profiles of respondents and small and medium-sized businesses are shown in Table 2 and Table 3. 


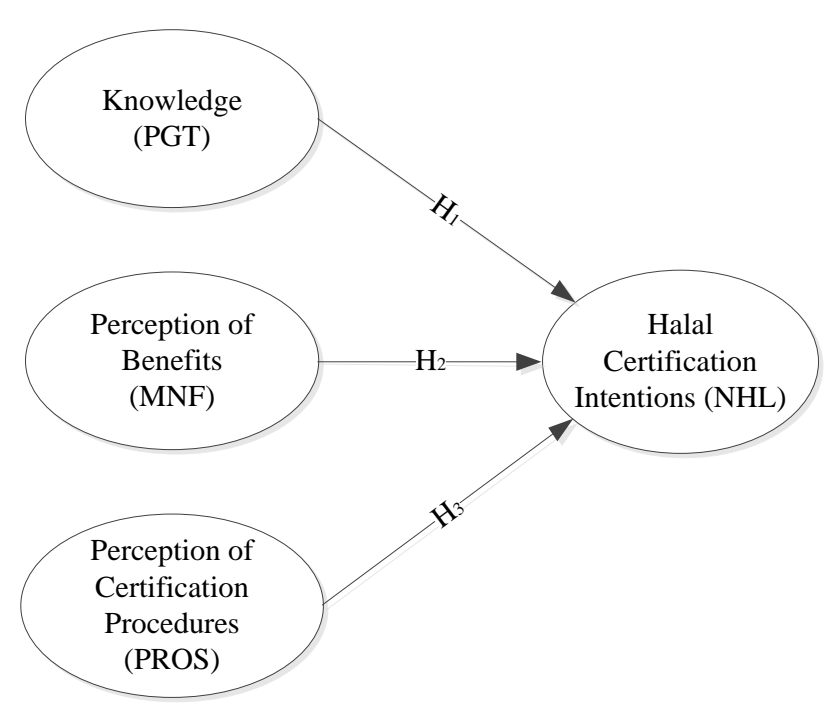

Fig. 1. Research model framework

Table 2. Profile of respondents

\begin{tabular}{ccrr}
\hline & Indicator & Quantity & Percentage \\
\hline \multirow{2}{*}{ Religion } & Islam & 78 & $79.59 \%$ \\
& Non-Islam & 20 & $20.41 \%$ \\
\hline \multirow{2}{*}{ Agender } & Male & 52 & $53.06 \%$ \\
& Female & 46 & $46.94 \%$ \\
\hline \multirow{3}{*}{ Education } & $<25$ years & 1 & $1.02 \%$ \\
& $25-34$ years & 12 & $12.24 \%$ \\
& $35-44$ years & 25 & $25.51 \%$ \\
& $45-54$ years & 44 & $44.90 \%$ \\
& $55-64$ years & 13 & $13.27 \%$ \\
& Not completed in primary & 3 & $3.06 \%$ \\
\hline school & 1 & $1.02 \%$ \\
& Primary School & 12 & $12.24 \%$ \\
& Middle Schol & 19 & $19.39 \%$ \\
& High School & 48 & $48.98 \%$ \\
& Associate degree & 5 & $5.10 \%$ \\
& Undergraduate & 12 & $12.24 \%$ \\
& Postgraduate & 0 & $0.00 \%$ \\
& Others & 1 & $1.02 \%$ \\
\hline
\end{tabular}

\subsection{Data Analysis Technique}

Data analysis was carried out using a systematic approach, including concise statistical tools and an assessment of test models. Descriptive statistics were used to describe the respondents' characteristics, the SME profile, the outcomes of knowledgelevel assessment, interpretation of advantages, perceived convenience of halal certification, and the intention/awareness of halal certification. The research analysis was used to assess the model and to illustrate objectively the hypothesis presented in the report. The evaluation of the theoretical model was carried out using the Structural 
Equation Model-Partial Least Square (SEM-PLS) method. SEM-PLS was used in this analysis, owing to the predictive aspect of the research. SEM-PLS is an effective analysis tool because it is accurate when analyzing data with a small sample size [2427]. We used SPSS 24 and Smart-PLS 3.2.7 to assist the data processing.

Table 3. SME Profiles

\begin{tabular}{ccrr}
\hline \multicolumn{1}{c}{ Indicator } & & Quantity & Percentage \\
\hline Business life & $<$ 3 years & 4 & $4.08 \%$ \\
& 3-5 years & 18 & $18.37 \%$ \\
& 6 - 10 years & 36 & $36.73 \%$ \\
& $11-15$ years & 24 & $24.49 \%$ \\
& $16-20$ years & 5 & $5.10 \%$ \\
Source of capital & $>20$ years & 11 & $11.22 \%$ \\
\hline & Equity of company & 89 & $90.82 \%$ \\
& Cooperation & 3 & $3.06 \%$ \\
Home industry product & Loan & 6 & $6.12 \%$ \\
\hline license & Available & 27 & $27.55 \%$ \\
& Not available & 71 & $72.45 \%$ \\
\hline
\end{tabular}

\section{Results and Discussion}

\subsection{Descriptive Statistics of Research Variables}

Table 4 shows Descriptive statistics for each measurement indicator. The Knowledge (PGT) had a high average perception value.

Table 4. Descriptive statistics measurement indicators

\begin{tabular}{cccccc}
\hline Indicator & Minimum & Maximum & Mean & Total mean & $\begin{array}{c}\text { Deviation } \\
\text { Standard }\end{array}$ \\
\hline PGT1 & 3.000 & 5.000 & 4.398 & 4.422 & 0.532 \\
PGT2 & 2.000 & 5.000 & 4.398 & & 0.587 \\
PGT3 & 3.000 & 5.000 & 4.469 & & 0.541 \\
\hline MNF1 & 3.000 & 5.000 & 4.061 & 4.058 & 0.426 \\
MNF2 & 3.000 & 5.000 & 4.082 & & 0.423 \\
MNF3 & 3.000 & 5.000 & 4.031 & & 0.442 \\
\hline PROS1 & 1.000 & 5.000 & 3.296 & 3.319 & 0.707 \\
PROS2 & 2.000 & 5.000 & 3.286 & & 0.658 \\
PROS3 & 1.000 & 5.000 & 3.265 & & 0.794 \\
PROS4 & 2.000 & 5.000 & 3.429 & & 0.642 \\
\hline NHL1 & 2.000 & 5.000 & 3.980 & 3.983 & 0.517 \\
NHL2 & 2.000 & 5.000 & 4.000 & & 0.497 \\
NHL3 & 2.000 & 5.000 & 3.969 & & 0.649 \\
\hline
\end{tabular}

\subsection{Evaluation of Measurement Model}

Alpha Cronbach assessed the reliability test. It was the most commonly used tool for evaluating internal consistency [25]. The acceptance limit for the Cronbach Alpha value was $>0.70$. Table 5 indicates that the Cronbach Alpha value for all variables reached the acceptance value (0.70). The loading factor value for confirmatory research was $>0.70$, while the loading factor value of 0.50 was still acceptable for exploratory 
research [25]. The loading factor of all indicators in Table 5 was between 0.742-0.964. This value means that the construct meets the requirements for construct validity. The t-statistics and $\mathrm{p}$-statistics in Table 5 indicate that all measurement factors are essential for measuring the model. The Convergence Validity Evaluation was evaluated by comparison to Composite Reliability (CR) and Average Variance Extracted (AVE) [25]. The acceptance level for the CR value is more than 0.70 , and the acceptance limit for the AVE value is 0.50 [25]. Table 5 indicates that the CR and AVE values for all factors reached the approval value. It showed that the questionnaire met the requirements for convergent validity. The results of the discriminant validity are shown in Table 6 and Table 7.

Table 5. Reliability and validity

\begin{tabular}{ccrrrrrr} 
Variable & Indicator & Loading factor & T-value & P-value & CR & AVE & $\begin{array}{c}\text { Alpha } \\
\text { Cronbach }\end{array}$ \\
\hline PGT & PGT1 & 0.953 & 5.466 & 0.000 & 0.930 & 0.815 & 0.900 \\
& PGT2 & 0.836 & 4.179 & 0.000 & & & \\
& PGT3 & 0.916 & 5.474 & 0.000 & & & \\
\hline MNF & MNF1 & 0.799 & 9.508 & 0.000 & 0.857 & 0.667 & 0.752 \\
& MNF2 & 0.808 & 11.070 & 0.000 & & & \\
& MNF3 & 0.843 & 12.307 & 0.000 & & & \\
PROS & PROS1 & 0.964 & 3.680 & 0.000 & 0.924 & 0.754 & 0.917 \\
& PROS2 & 0.806 & 3.976 & 0.000 & & & \\
& PROS3 & 0.942 & 4.003 & 0.000 & & & \\
& PROS4 & 0.742 & 3.499 & 0.001 & & & \\
NHL & NHL1 & 0.936 & 38.829 & 0.000 & 0.934 & 0.826 & 0.895 \\
& NHL2 & 0.943 & 48.374 & 0.000 & & & \\
& NHL3 & 0.843 & 16.726 & 0.000 & & & \\
\hline
\end{tabular}

\begin{tabular}{ccccc} 
& \multicolumn{4}{c}{ Table 6. Cross loading } \\
& PGT & MNF & PROS & NHL \\
\hline PGT1 & $\mathbf{0 . 9 5 3}$ & 0.284 & 0.093 & 0.298 \\
PGT2 & $\mathbf{0 . 8 3 6}$ & 0.239 & -0.009 & 0.102 \\
PGT3 & $\mathbf{0 . 9 1 6}$ & 0.238 & 0.108 & 0.155 \\
MNF1 & 0.168 & $\mathbf{0 . 7 9 9}$ & 0.130 & 0.245 \\
MNF2 & 0.324 & $\mathbf{0 . 8 0 8}$ & 0.003 & 0.290 \\
MNF3 & 0.200 & $\mathbf{0 . 8 4 3}$ & 0.072 & 0.313 \\
PROS1 & 0.109 & 0.068 & $\mathbf{0 . 9 6 4}$ & 0.179 \\
PROS2 & 0.228 & 0.080 & $\mathbf{0 . 8 0 6}$ & 0.043 \\
PROS3 & 0.012 & 0.070 & $\mathbf{0 . 9 4 2}$ & 0.143 \\
PROS4 & 0.165 & -0.020 & $\mathbf{0 . 7 4 2}$ & -0.020 \\
NHL1 & 0.251 & 0.337 & 0.173 & $\mathbf{0 . 9 3 6}$ \\
NHL2 & 0.233 & 0.356 & 0.132 & $\mathbf{0 . 9 4 3}$ \\
NHL3 & 0.160 & 0.241 & 0.153 & $\mathbf{0 . 8 4 3}$ \\
\hline
\end{tabular}




\begin{tabular}{ccccc}
\multicolumn{5}{c}{ Table 7. Discriminant validity construct } \\
\hline & PGT & MNF & PROS & NHL \\
\hline PGT & $\mathbf{0 . 9 0 3}$ & & & \\
MNF & 0.285 & $\mathbf{0 . 8 1 7}$ & & \\
PROS & 0.085 & 0.080 & $\mathbf{0 . 8 6 9}$ & \\
NHL & 0.241 & 0.348 & 0.167 & $\mathbf{0 . 9 0 9}$ \\
\hline
\end{tabular}

\subsection{Hypothesis Testing on Structural Models}

Table 8 summarizes the test hypotheses of the relationship between the independent variables and the dependent variable. The independent variables in this study were halal knowledge (PGT), perception of halal certification benefits (MNF), and knowledge of halal certification procedures (PROS). Awareness/intention to carry out Halal Certification (NHL) was a dependent variable. Therefore, only one theory, the H2 hypothesis, was statistically confirmed. The perception of benefits of halal certification (MNF) had a strong and significant impact on the awareness/intention of SME entrepreneurs to carry out halal certification. Fig. 2 shows the structural model in the SMART-PLS. The structural model produced a coefficient of determination $\left(\mathrm{R}^{2}\right)$ of 0.160 . This value indicated the variance of the variables NHL was described by three independent variables PGT, MNF, and PROS, by 16 percent. Hence, $84 \%$ of the variance in the halal certification awareness variable was not explained in the structural model formed in this study.

\subsection{Discussion}

The Descriptive Statistics at Knowledge Level (PGT) findings in Table 4 indicate that the SME respondents have a good knowledge of halal. However, based on the results of the $\mathrm{H} 1$ hypothesis, knowledge of halal (PGT) does not have a significant impact on the intention/awareness to conduct halal certification (NHL). The findings of this study were different from the reports of the study by Waluyo [18]. That research was shown that religious knowledge has a significant impact on the awareness of food producers to carry out halal certification. Simanjuntak and Dewantara [28] found that knowledge of halal labels on food packaging did not significantly impact consumer behavior. The impact of knowledge (PGT) on carrying out Halal Certification (NHL) is not significant due to two factors. First, there are different respondents between this study and the research by Waluyo [18]. Respondent's research focused on food producers from SMEs. Second, knowledge factors might not affect intention/awareness directly but through mediator variables, such as attitude.

The assessment of the variable perception of Halal Certification Benefits (MNF) shows that SME entrepreneurs generally agree that Halal Food Certification provides benefits. The results were consistent with the results of previous studies, which concluded that SME entrepreneurs had a positive perception of halal certification [20]. Positive perceptions of benefits (MNF) have been shown to affect the intent/awareness of halal certification (NHL) SME entrepreneurs. The results of the H2-hypothesis test confirmed the findings of Waluyo [18]. The study concluded that the motivation to make profits encourages producers to carry out Halal Certification. However, the results of this study contradicted the results of studies by Ardial [29].

Lack of socialization was a factor in the lack of understanding between respondents regarding halal certification procedures (PROS). Respondents considered 
that the procedure for handling halal certification was relatively complex. The results of the H3 hypothesis test indicated the perception of the ease of the halal certification process (PROS). It does not significantly impact the Awareness of Halal Certification (NHL) [12-14, 30]. The Government has provided free Halal Certification Facilitation services to SMEs. However, the system was only provided to register Halal Certification, while the extension phase had to be followed separately. The low level of recognition of halal certification was not only faced by SMEs in Indonesia. The level of awareness of halal certification among Malaysian SMEs also considered being still low [31]. However, the performance of SMEs was expected to increase by halal certification [32] [33].

Table 8. Hypothesis test results

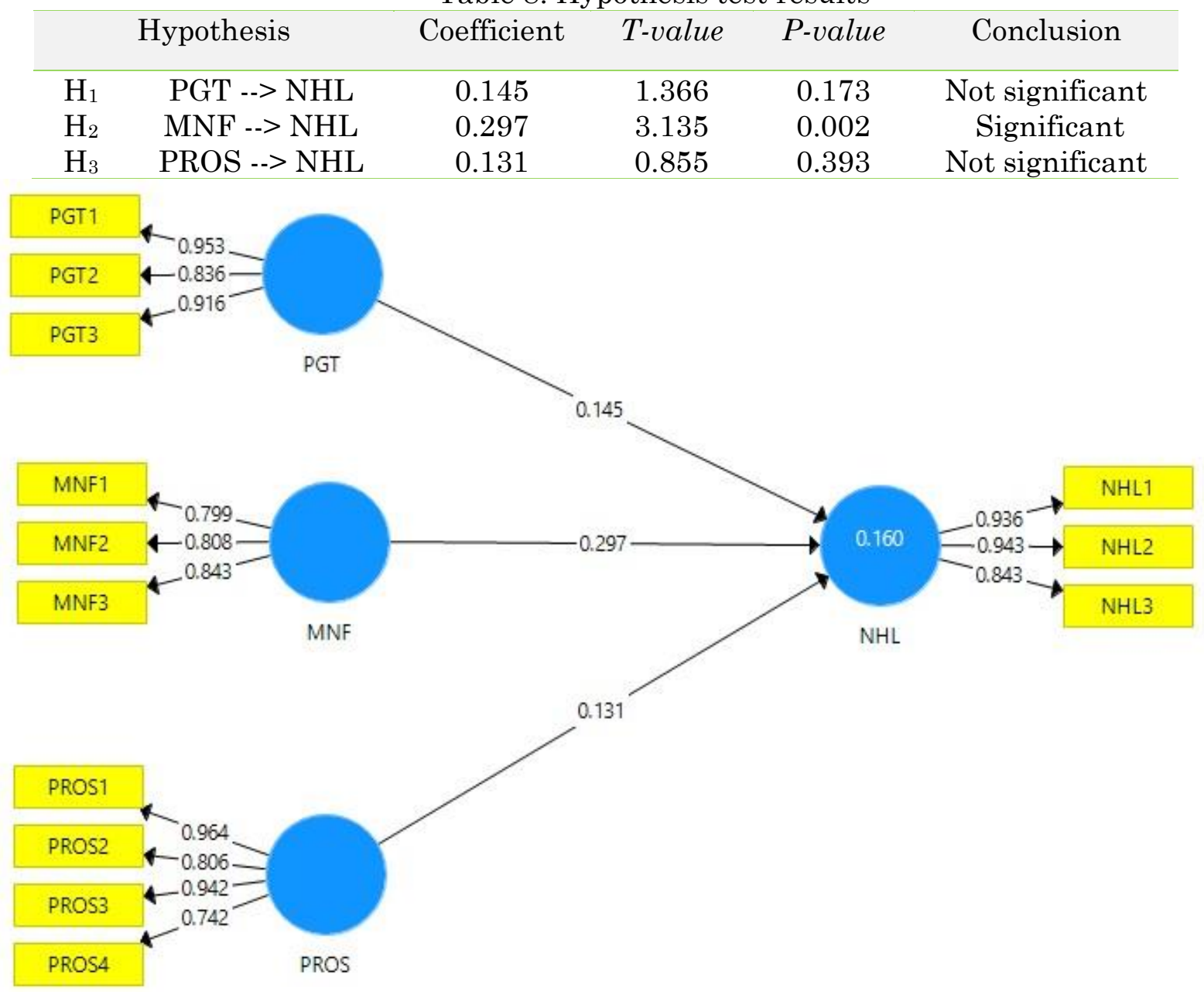

Fig. 2. Structural Model

\section{Conclusion}

The halal/haram evaluation results indicate that the SME food business in Surakarta, Indonesia has good knowledge of halal/haram. The benefits of halal certification indicated that halal food product certification provides several benefits for SMEs. Three hypotheses have a positive correlation. However, only the H2 hypothesis had a positive effect on the awareness/intention of halal certification. It indicated that the perception of SMEs does not impact actual actions to take care of halal certification. Further research may be undertaken to identify other factors that influence the 
awareness/intention of halal certification by including moderate, intermediate variables. Another research gap was identifying critical factors that influence the success of SMEs in obtaining Halal Certificates.

\section{Acknowledgments}

The author would like to thank the Directorate for Research and Community Service, the Directorate-General for Research and Technology Strengthening the Ministry of Research, Technology, and Higher Education of the Republic of Indonesia for providing financial support for this study by research contract nu mber 003/LPPM-USB / PDP / III/2018.

\section{References}

[1] S. Cooper. (2017, 20 August). Global Halal Food Market Size, Share, 20142024 I Industry Report," Halal Food Market Size and Forecast, By Application (Processed Food \& Beverages, Bakery Products and Confectionary), and Trend Analysis, 2014 - 2024, 2017. Available: https://www.hexaresearch.com/research-report/global-halal-food-market

[2] I. Giyanti and E. Indriastiningsih, "Pemetaan UKM Kuliner Kota Surakarta Berdasarkan Status Sertifikasi Halal," Jurnal Teknologi, vol. 11, pp. 87-91, 2018. https://doi.org/10.1108/JIMA-04-2014-0033.

[3] Y. A. Aziz and N. V. Chok, "The role of Halal awareness, Halal certification, and marketing components in determining Halal purchase intention among non-Muslims in Malaysia: A structural equation modeling approach," Journal of International Food \& Agribusiness Marketing, vol. 25, pp. 1-23, 2013. https://doi.org/10.1080/08974438.2013.723997.

[4] A. Haque, A. Sarwar, F. Yasmin, A. K. Tarofder, and M. A. Hossain, "NonMuslim consumers' perception toward purchasing halal food products in Malaysia," Journal of Islamic Marketing, vol. 6, pp. 133-147, 2015. https://doi.org/10.1108/JIMA-04-2014-0033.

[5] R. Golnaz, M. Zainalabidin, S. Mad Nasir, and F. Eddie Chiew, "NonMuslims' awareness of Halal principles and related food products in Malaysia," International Food Research Journal, vol. 17, pp. 667-674, 2010.

[6] G. Rezai, Z. Mohamed, and M. Nasir Shamsudin, "Non-Muslim consumers' understanding of Halal principles in Malaysia," Journal of Islamic $\begin{array}{lllll}\text { Marketing, } & \text { vol. } & 3, & \text { pp. } & \end{array}$ https://doi.org/10.1108/17590831211206572.

[7] V. N. Mathew, "Acceptance on halal food among non-Muslim consumers," Procedia-Social and Behavioral Sciences, vol. 121, pp. 262-271, 2014. https://doi.org/10.1016/j.sbspro.2014.01.1127.

[8] F. Ismail and K. B. Nasiruddin, "Perception of Non-Muslim consumers towards Halal products in Malaysia," International Journal of Accounting and Business Management, vol. 2, pp. 128-133, 2014. 
[9] M. W. Wibowo and F. S. Ahmad, "Non-Muslim consumers' halal food product acceptance model," Procedia Economics and Finance, vol. 37, pp. 276-283, 2016. https://doi.org/10.1016/S2212-5671(16)30125-3.

[10] F. R. Azmi, H. Musa, H. Sihombing, and F. S. Fen, "Adoption factors of halal standards: The Malaysian perspectives," in Proceedings of the 3rd International Halal Conference (INHAC 2016), 2018, pp. 315-329. https://doi.org/10.1007/978-981-10-7257-4_29.

[11] S. Zailani, K. Kanapathy, M. Iranmanesh, and M. Tieman, "Drivers of halal orientation strategy among halal food firms," British Food Journal, vol. 117, pp. 2143-2160, 2015. https://doi.org/10.1108/BFJ-01-2015-0027.

[12] T. Maryati, R. Syarief, and R. Hasbullah, "Analisis Faktor Kendala dalam PengajuanSertifikat Halal.(Studi Kasus: Pelaku Usaha Mikro, Kecil dan Menengah Makanan Beku diJabodetabek)," Jurnal Ilmu Produksi dan Teknologi Peternakan, vol. 4, pp. 364-371, 2016. https://doi.org/10.29244/jipthp.4.3.364-371.

[13] S. Prabowo, A. Abd Rahman, S. Ab Rahman, and A. A. Samah, "Revealing factors hindering halal certification in East Kalimantan Indonesia," Journal of Islamic Marketing, vol. 6, pp. 268-291, 2015. https://doi.org/10.1108/JIMA-05-2014-0040.

[14] R. D. Kusumastuti and R. Rachmawati, "Motives and challenges of small businesses for halal certification: the case of Indonesia," World Journal of Social Sciences, vol. 7, pp. 136-146, 2017.

[15] C.-L. Siaw and N. S. A. Rani, "A critical review on the regulatory and legislation challenges faced by halal start-up SMEs food manufacturers in Malaysia," Procedia-Social and Behavioral Sciences, vol. 57, pp. 541-548, 2012. https://doi.org/10.1016/j.sbspro.2012.09.1222.

[16] M. S. Ab Talib, "Motivations and benefits of halal food safety certification," Journal of Islamic Marketing, vol. 8, pp. 605-624, 2017. https://doi.org/10.1108/JIMA-08-2015-0063.

[17] M. S. Ab Talib, S. S. Md. Sawari, A. B. Abdul Hamid, and T. Ai Chin, "Emerging Halal food market: an Institutional Theory of Halal certificate implementation," Management Research Review, vol. 39, pp. 987-997, 2016. https://doi.org/10.1108/MRR-06-2015-0147.

[18] W. Waluyo, "Pengaruh Pemahaman Agama, Motivasi Mendapatkan Profit Dan Tingkat Pendidikan Terhadap Kesadaran Sertifikasi Halal Bagi Produsen Makanan Di Kabupaten Sleman Dan Bantul," INFERENSI: Jurnal Penelitian Sosial Keagamaan, vol. 7, pp. 75-98, 2013. http://dx.doi.org/10.18326/infsl3.v7i1.75-98.

[19] A. Rafiki and K. A. Wahab, "Influences of Islamic Practices on Small Firm Performance: A Study in North Sumatera, Indonesia," Islamic Management and Business, vol. 5, pp. 64-82, 2013.

[20] M. Abdul, H. Ismail, and M. Mustapha, "Halal food certification: case of Malaysian SME entrepreneurs," China-USA Business Review, vol. 12, 2013. 
[21] P. R. Tahir, J. Hanaysha, and M. Sultana, "Level of success of halal small and medium entrepreneurs in Malaysia," Asian Journal of Scientific Research, vol. 9, pp. 214-218, 2016.

[22] A. H. Ngah, Y. Zainuddin, and R. Thurasamy, "Modelling of Halal Warehouse Adoption Using Partial Least Squares (PLS)," Selangor Business Review (SBR), vol. 1, 2014.

[23] LPPOM-MUI, "Panduan Umum Sistem Jaminan Halal LPPOM-MUI," ed: LPPOM-MUI 2008.

[24] R. E. A. J. F. Hair, R. L. Tatham, and W. C. Black, Multivariate Data Analysis, 5 ed. Engelwood Cliffs: Prentice-Hall, 1998.

[25] R. Indriartiningtias, "Validasi Model Transfer Pengetahuan Dari Perguruan Tinggi Ke Industri Kecil," Jurnal Teknik Industri, vol. 12, pp. 118-125, 2012. https://doi.org/10.22219/JTIUMM.Vol12.No2.118-125.

[26] N. U. Handayani, H. Santoso, and A. I. Pratama, "Faktor-Faktor yang memengaruhi Peningkatan Daya Saing Klaster Mebel di Kabupaten Jepara," Jurnal teknik industri, vol. 13, pp. 22-30, 2012. https://doi.org/10.22219/JTIUMM.Vol13.No1.22-30.

[27] W. W. Chin, "How to write up and report PLS analyses," in Handbook of partial least squares, ed: Springer, 2010, pp. 655-690.

[28] M. Simanjuntak and M. M. Dewantara, "The Effects of Knowledge, Religiosity Value, and Attitude on Halal Label Reading Behavior of Undergraduate Students."

[29] A. C. L. Ardial, "Pemahaman Pengusaha Bisnis Kuliner Terhadap Sertifikasi Halal Majelis Ulama Indonesia (MUI) Dalam Produk Makanan Di Yogyakarta," UIN Sunan Kalijaga, Yogyakarta, 2017.

[30] M. S. Ab Talib, A. B. Abdul Hamid, and T. Ai Chin, "Motivations and limitations in implementing Halal food certification: a Pareto analysis," British Food Journal, vol. 117, pp. 2664-2705, 2015. https://doi.org/10.1108/BFJ-02-2015-0055.

[31] N. M. Tawil, S. Ramlee, J. Jaafar, and F. M. Saat, "An overview of foodpreneur awareness among small and medium-sized enterprises (SME) of halal certification," Asian Social Science, vol. 11, p. 91, 2015. https://doi.org/10.5539/ass.v11n21p91.

[32] M. S. Ab Talib, T. Ai Chin, and J. Fischer, "Linking Halal food certification and business performance," British Food Journal, vol. 119, pp. 1606-1618, 2017. https://doi.org/10.1108/BFJ-01-2017-0019.

[33] A. H. Yusuf, S. Abdul Shukor, and U. Ahmad Bustamam, "Halal certification vs business growth of food industry in Malaysia," Journal of Economics, Business and Management, vol. 4, pp. 247-251, 2016. https://doi.org/10.7763/JOEBM.2016.V4.399. 